\title{
Total Coliforms and Escherichia coli in Surface and Subsurface Water from a Sugarcane Agroecosystem in Veracruz, Mexico
}

\author{
Juan Valente Megchún-García ${ }^{1}$, Cesáreo Landeros-Sánchez ${ }^{1}$, Alejandra Soto-Estrada ${ }^{1}$, María del Refugio \\ Castañeda-Chávez ${ }^{3}$, Juan Pablo Martínez-Dávila ${ }^{1}$, Iouri Nikolskii-Gavrilov ${ }^{2}$, Itzel Galaviz-Villa ${ }^{3}$ \\ \& Fabiola Lango-Reynoso ${ }^{3}$ \\ ${ }^{1}$ Colegio de Postgraduados, Campus Veracruz, Manlio Fabio Altamirano, Veracruz, México \\ ${ }^{2}$ Colegio de Postgraduados, Campus Montecillo, Montecillo, Texcoco, México \\ ${ }^{3}$ Instituto Tecnológico de Boca del Río, Carretera Veracruz, Boca del Río, Veracruz, México \\ Correspondence: Cesáreo Landeros-Sánchez, Colegio de Postgraduados, Campus Veracruz Apartado postal 421, \\ Veracruz, Ver., México. Tel: 1-229-201-0770. E-mail: clandero@colpos.mx
}

Received: January 25, 2015 Accepted: April 15, 2015 Online Published: May 15, 2015

doi:10.5539/jas.v7n6p110 URL: http://dx.doi.org/10.5539/jas.v7n6p110

\begin{abstract}
Water contamination is a phenomenon of global concern resulting from human activities. Coliform bacteria reduce water quality and negatively affect public health. The pollution of surface and groundwater by coliform bacteria, including Escherichia coli, originate, in general, from point sources of pollution derived from human settlements, such as those located in Module I-1, Irrigation District 035, La Antigua, Veracruz, Mexico. The objective of this study was to assess the level of contamination of surface and groundwater by coliform bacteria and $E$. coli, as well as to identify point sources of water contamination by these bacteria in the sugarcane agroecosystem of Irrigation Module I-1, La Antigua. Sampling sites included deep wells, irrigation canals and natural streams near point sources of pollution. The determination of total coliform bacteria and E. coli were made in accordance with Mexican Standard NMX-AA-042-1987. Total coliform results revealed differences between groundwater (198.6 MPN/100 mL) and surface water concentrations $(52,419.2 \mathrm{MPN} / 100 \mathrm{~mL})(\mathrm{p}<0.05)$, and between irrigation water $(76,501.1 \mathrm{MPN} / 100 \mathrm{~mL})$ and concentrations in natural streams $(28,337.3 \mathrm{MPN} / 100 \mathrm{~mL})$. The highest concentration of $E$. coli was found in groundwater and surface water samples from the municipality of La Antigua. The primary sources of contamination are the discharges from drains and septic tanks. Total coliform values exceeded permissible limits established by NOM-127-SSA1-1994 that regulates the permissible water quality limits for human use and consumption. The presence of $E$. coli represents a significant public health risk.
\end{abstract}

Keywords: water contamination, irrigation canals, sugarcane, enteric bacteria

\section{Introduction}

Water contamination is a global concern for humanity, and is defined as an addition of energy or substances which alter the natural state of the environment, and are caused by anthropogenic activities on the surface of the earth (Krupa, 1999; Pérez y Landeros, 2009; Rebolledo et al., 2011). On the other hand, water pollution is the contamination of natural water bodies by chemical, physical, radioactive or pathogenic microbial substances directly or indirectly discharged into water bodies without adequate treatment to remove harmful compounds (Hogan, 2014). Contamination can be atmospheric, aquatic, edaphic, genetic, chemical and biological. As well, pollution and contamination are classified as being from point (entering the environment from definable points; e.g. a drainage pipe) or non-point sources (entering the environment diffusely; e.g. surface runoff). Microbiological contamination can be due to viruses, bacteria, protozoa and fungi that come mainly from sewage discharge and other human activities, as well as physicochemical and ecophysical processes occurring in aquatic systems due to increased human population levels and industrial development (Wong \& Barrera, 1996; Martinez, Fonseca, Ortega, \& Garcia, 2009; Lango et al., 2012). Bacterial contamination from total coliforms in surface water and groundwater originates from point sources such as latrines, septic tanks, trails, cattle pens or stables, discharges of untreated sewage and runoff of rainwater containing fecal material (Sasson, 1993; Herrero et al., 2000; Perdomo, Casanova, \& Ciganda, 2001; Castañeda, Pardio, Orrantia, \& Lango, 2005; Camargo \& Alonso, 2007; Rebolledo et al., 2011). Non-point sources of microbiological and physicochemical contamination are associated with high production levels in agroecosystems. It is estimated that a person can defecate between 100 
to 500 million coliform bacteria per gram of fecal matter and generate a number of infectious diseases such as typhoid, paratyphoid, cholera, infant diarrhea and bacillary dysentery (caused by Shigella bacteria) (Orozco \& Gutiérrez, 1983; Landeros-Sánchez et al., 2012). Gastrointestinal diseases related to bacterial contamination are influenced by economic, health and cultural factors (Camargo \& Alonso, 2007). Of particular importance is the bacterium Escherichia coli which is an indicator of fecal contamination, and is well-studied genetically, biochemically and physiologically (Ramirez, Contreras, \& Gómez, 2005).

Ecosystems have biological, ecological and aesthetic value, but agroecosystems have social values in terms of food production and other forms of use or consumption. The agroecosystem concept is presented as an option for efficient economic, social and environmental management, and as a conceptual model of farming with a minimum level of human cybernetic control. It is the optimal unit for studying agriculture and its transformation because it is integrated into regional agricultural and rural systems through human production-consumption chains, and is affected by politics and the culture of public and private institutions. The agroecosystem is an open system built from the social modification of a natural system, has dynamic feedback and control processes, and is internally and externally regulated in response to internal and external variations in its environment. The spatial area, biodiversity and objectives of an agroecosystem depend on the type of controller that regulates the resources it manages and its complex interactions with the environment (Martínez, Gallardo, Bustillo, \& Pérez, 2011; Del Angel, Diaz, Guajardo, \& Linares, 2011; Galaviz-Villa, Landeros-Sánchez, Castañeda-Chávez, \& Lango-Reynoso, 2012). In the present study, the focus on the agroecosystem was from the structural-functionalist perspective, and did not consider the involvement of a driver, as is done when only one process occurring in the agroecosystem is studied, such as bacteriological contamination. Here, the sugarcane agroecosystem is highlighted by the cultivation area of Irrigation Module I-1, La Antigua, Veracruz, Mexico, within which the aquatic sampling points and small cities and rural villages are located. The surface area covered by sugarcane in the study area is 13,793 hectares, and includes portions of the municipalities of La Antigua, Paso de Ovejas, Puente Nacional and Úrsulo Galván. Irrigation Module I-1 was legally established as a Civil Association (A.C.) in 1993, and is called Asociación de Usuarios de Riego del Modulo de Riego I-1, La Antigua, A.C. Subsequent references to the Association will be made as Irrigation Module I-1, La Antigua.

Extreme weather can cause spills, runoff and infiltration of wastewater containing fecal matter into streams, swamps, reservoirs and coastal waters that increase the volume of contaminated surface water and groundwater (Perdomo et al., 2001; Bautista, Aguilar, \& Batllori, 2011). As well, human settlements within an area contribute to pollution and contamination (Juarez, Martinez, Diaz, Perez, \& Brust, 1990; Perdomo et al., 2001; Galaviz-Villa et al., 2012; Landeros-Sánchez et al., 2012). Contamination from total coliforms and E. coli in surface and groundwater is also related to political and technological actions, such as the lack of effective enforcement of the National Water Act and Mexican Official Standards (Moreno et al., 2002). Chemical or biological contamination of aquifers is considered an irreversible phenomenon that must be addressed by relevant authorities (De las Heras \& Moreno, 2005). Based on this, the hypothesis of this work consider that point and non-point sources of pollution located in sugarcane Irrigation Module I-1, La Antigua, Veracruz, Mexico, are the main contaminants of surface and groundwater by coliform bacteria, including E. coli. Thus, this study was conducted to assess total coliform bacteria and $E$. coli contamination in surface and groundwater in sugarcane agroecosystem, Irrigation Module I-1, La Antigua, Veracruz, Mexico.

\section{Method}

\subsection{Characterization of the Study Area}

The research was conducted in sugarcane Irrigation Module I-1, La Antigua, Veracruz, Mexico, located in Irrigation District 035 (Figure 1). The study area is located in the central portion of the state of Veracruz between $19^{\circ} 09^{\prime}$ and $19^{\circ} 25^{\prime} \mathrm{N}$ and $96^{\circ} 17^{\prime}$ and $96^{\circ} 25^{\prime} \mathrm{W}$, and covers 13,793 hectares and supplies 247,179 kilometers of drainage for the municipalities of La Antigua, Manlio Fabio Altamirano, Paso de Ovejas, Puente Nacional and Úrsulo Galván, whose populations are 25 855, 23 807, 34 141, 22 510, and 30260 people, respectively. 


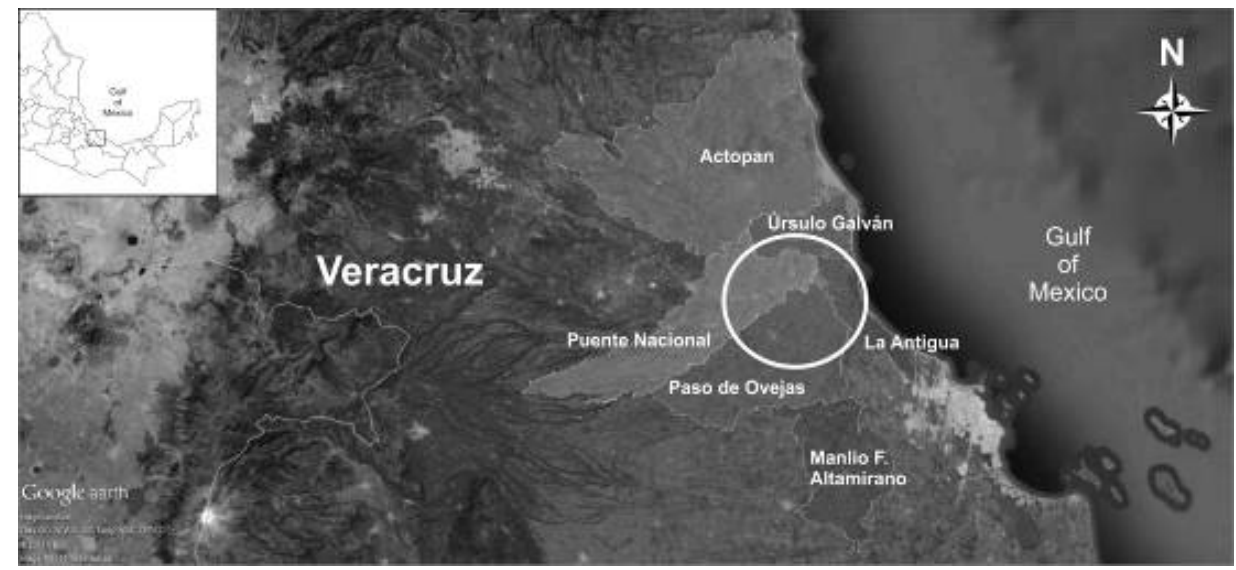

Figure 1. Location of the study area (Irrigation Module I-1, La Antigua, Veracruz, Mexico)

\subsection{Diagnostic Phase of the Study Area}

To determine the sampling points for bacterial contamination, data were provided by technicians from the Irrigation Module I-1, La Antigua A.C., which consisted of identifying mapped locations and distributions of groundwater and surface water supplies in the field during October to December, 2012. The point sources of bacterial contamination were identified visually with help of users of the irrigation Module. Sampling points (32) were within the municipalities of La Antigua, Paso de Ovejas and Úrsulo Galván, and included groundwater sources from deep wells (for drinking water and irrigation), domestic wells, natural surface waters (Río La Antigua, Río Chico, and Río Tolome) and irrigation canals (main distribution frame, main channel, side channel, Drain 1).

\subsection{Sampling Groundwater and Surface Water}

Water samples were collected from wells, waterwheels, irrigation canals and streams according to Mexican standard protocols NOM-230-SSA1-2002, NMX-AA-003-1980 and NOM-014-SSA1-1993 in February 2013. Samples were transported to Instituto Tecnologico de Boca del Rio, Laboratorio de Investigación en Recursos Acuáticos (LIRA).

\subsection{Analysis of Total Coliforms and E. coli}

Total coliforms and E. coli were determined for each sample according to Mexican standard operating protocol NMX-AA-042. The most probable number (MPN) was determined for total coliforms while E. coli was assessed using presence/absence. For this, the Colilert method was used and consisted in utilizing Quanti-Trays of 48 holes. In a sterile beaker, $90 \mathrm{~mL}$ of sterile distilled water was mixed with $10 \mathrm{~mL}$ of each sampling water and the Colilert reagent; the mixture was poured on the Quanti-Trays, which were incubated at $35 \pm 1{ }^{\circ} \mathrm{C}$ for 24 and $48 \mathrm{~h}$ to determine total coliforms and E. Coli, respectively. Three replicates per sample of water were used.

\subsection{Statistical Analysis}

For this research work three replicates were used in each water sampling site (32). The results analytic process was carried out by means of graphic parametric variance analyses (F test) using "Statistica" Version 11 Software. In Figure 2 and 3 can be observed that the populations which are statistical different do not overlap. The value of $Z=1.645$ is the point where the confidence probability of a standard normal distribution is equal to $95 \%$ and if the boxes of the mean values of the populations do not overlap then it is interpreted that these populations are statistical different. Therefore, there are statistical differences between the ground and surface populations (Figure 2) and between La Antigua and the municipalities of Paso de Ovejas and Ursulo Galván (Figure 3).

\section{Results and Discussion}

Concentrations of total coliforms were higher in surface waters $(52,419.2 \mathrm{MPN} / 100 \mathrm{~mL})$ than in groundwater $(198.6 \mathrm{MPN} / 100 \mathrm{~mL})(\mathrm{P}<0.01)$ (Figure 2); this might indicate the existence of point sources of bacterial contamination within sugarcane Irrigation Module I-1, La Antigua. In Mexico, it is reported that homes, small factories, roads and hospitals discharge thousands of cubic meters of waste per year into channels, drains, main reservoirs and streams (Gordillo et al., 2010). Méndez, San Pedro, Castillo, and Vazquez (2010) and Camargo and Alonso (2007) reported that coliform concentrations in groundwater and surface water imply the presence of bacterial genera Citrobacter, Enterobacter, Escherichia, Hafnia, Klebsiella, Serratia and Yersinia; so the 
presence of these bacteria could pose a risk to human health in the communities surrounding sugarcane Irrigation Module I-1, La Antigua, Veracruz.

Total coliform concentrations varied among municipalities, with La Antigua having the highest concentration $(38,000 \mathrm{MNP} / 100 \mathrm{~mL})$ followed by Paso de Ovejas $(11,000 \mathrm{MPN} / 100 \mathrm{~mL})$ and Úrsulo Galván $(4,500 \mathrm{MPN} / 100$ $\mathrm{mL}$ ) (Figure 3). Thus, it is likely that there are point sources of bacterial contamination affecting water irrigation channels, streams, shallow water and deep wells. Even though the water samples were equally distributed between regions, the differences in the coliform concentrations appeared to be so because of the presence of the main cities, some rural villages, hospitals, and a sugarcane factory, which likely contributed through their various waste discharges to the referred high bacteria concentrations.

The concentration of total coliforms was higher in water from irrigation canals; followed by streams, shallow water and deep wells $(\mathrm{P}<0.01$, Table 1$)$. No statistically significant differences between shallow and deep wells were found when using Fisher LSD Test. Total coliform levels in shallow and deep wells, streams and irrigation canals exceeded permissible limits established by Mexican Official Standard NOM-127-SSA1-1994 that regulates water quality for human use and consumption. However, total coliform concentrations from deep and shallow wells did not exceed the permissible limits for total coliforms established in Mexican Official Standard NOM-033-ECOL-1997, which regulates pollutants in treated wastewater to be reused in public services.

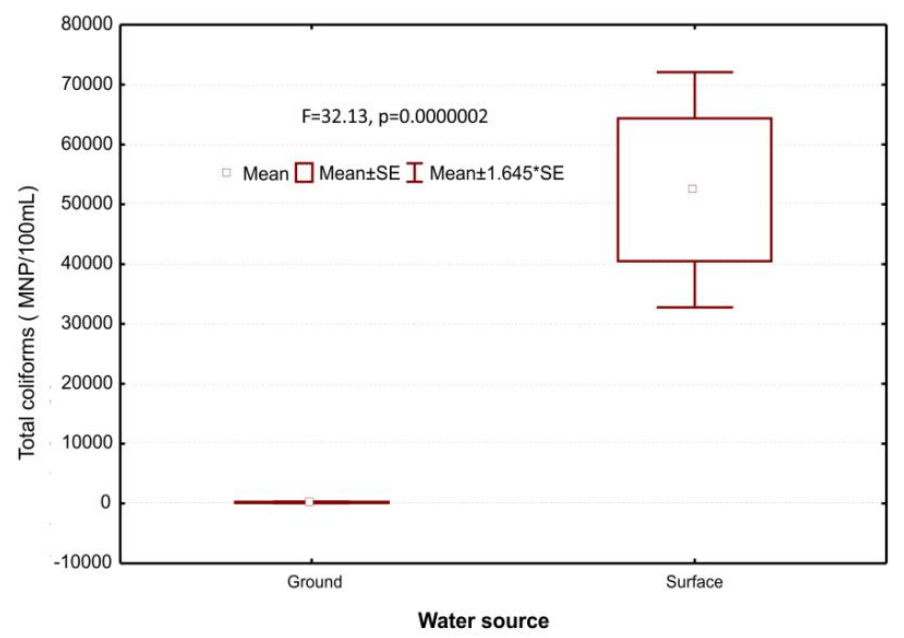

Figure 2. Total coliform bacteria in ground and surface water samples from Irrigation Module I-1, La Antigua, Veracruz

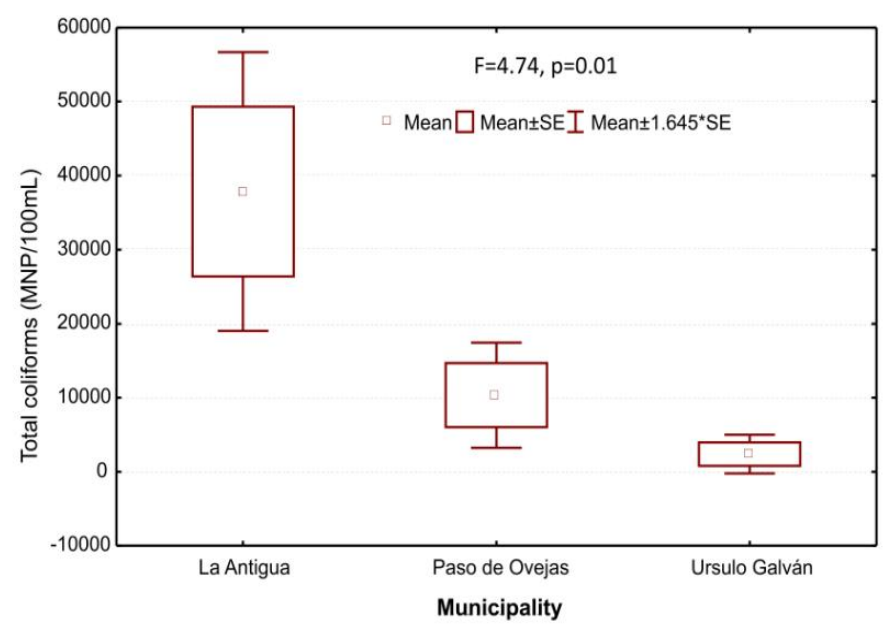

Figure 3. Total coliform concentrations found in ground and surface water from three municipalities in Irrigation Module I-1, La Antigua samples (sample data were combined in each municipality) 
Total coliform values found in this study (Table 1) exceeded the maximum concentrations of total coliforms reported for shallow water from 120 agricultural wells in the valley of San Luis Potosi, Mexico (2,400 MPN/100 $\mathrm{mL}$ ); values which also exceeded limits set for ecological criteria (CE-CCA-001/89) established by the Diario Oficial de la Federación Mexicana and by the Ley Federal de Derechos de Agua, 2009 (Sarabia, Cisneros, Aceves De, Durán, \& Castro, 2011). These criteria indicate that the organisms in fresh or sea water should not exceed $200 \mathrm{NMP} / 100 \mathrm{~mL}$.

The average total coliform concentration among the sampling points $(28,337.2 \mathrm{MPN} / 100 \mathrm{~mL})$ exceeded 300 MPN/100 mL reported by Chagas et al. (2006) from surface waters in Argentina. As well, Lango et al. (2012) and Landeros-Sánchez et al. (2012) reported that total coliforms in lagoon systems were affecting public health.

The total coliform concentrations in samples from the irrigation canals in Irrigation Module I-1 (Table 2) were higher in water leaving the canals. This occurs because some canal routes cross communities and are used by people to discharge sewage, domestic waste and that from animal husbandry activities. The irrigation water eventually mixes with streams and aquifers, resulting in the deterioration of water quality (Pacheco, Cabrera, \& Pérez, 2004). Coliform bacteria can survive in slow moving and highly polluted groundwater. The increased concentrations of coliform bacteria in irrigation canals probably indicate that the water also contains other pathogens (Perdomo et al., 2001).

Table 2 shows statistically significant differences among the total coliform concentrations in samples from three irrigation canals and Drain 1, with the latter having the highest mean value (129,332.5 MPN/100 mL). Drain 1 receives discharges from the Instituto Mexicano del Seguro Social (IMSS) clinic in the city of Cardel, Veracruz, wastewater runoff from the urban and rural zones in Irrigation Module I-1, La Antigua, and agrochemicals from sugarcane cultivation (Galaviz et al., 2012). The rate with which contamination occurs depends on chemical, physical and biological soil characteristics (Pacheco et al., 2004).

Table 1. Comparison of mean values for concentrations of total coliforms in samples of groundwater and surface water from Irrigation Module I-1, La Antigua, Veracruz, and relevant official Mexican standards

\begin{tabular}{ll}
\hline Water source & Total coliforms $(\mathrm{MPN} / 100 \mathrm{~mL})$ \\
\hline Deep wells & $87.3 \mathrm{c}$ \\
Shallow water wells & $309.9 \mathrm{c}$ \\
Streams & $28337.2 \mathrm{~b}$ \\
Irrigation canals & $76501.1 \mathrm{a}$ \\
NOM-127-SSA1-1994 & 2 \\
NOM-033-ECOL-1997 (Fecal coliforms) & $240-1000$ \\
\hline
\end{tabular}

Note. Mean values comparison by using Fisher LSD Test at a significance probability $\mathrm{p}<0.01$. The presence of different letters means that there exists a statistical difference. NOM $=$ Official Mexican standards, MPN=Most probable number.

Table 2. Mean concentrations of total coliforms in water samples entering and exiting irrigation canals in Irrigation Module I-1, La Antigua, Veracruz

\begin{tabular}{ll|ll}
\hline Irrigation canals & Total coliforms $(\mathrm{MPN} / 100 \mathrm{~mL})$ & Irrigation canals & Total coliforms $(\mathrm{MPN} / 100 \mathrm{~mL})$ \\
\hline Water entering & $52,951.5 \mathrm{~b}$ & Area sampled & $5,559.3 \mathrm{c}$ \\
Water exiting & $64,580.0 \mathrm{a}$ & Principal canal & $69,100.0 \mathrm{~b}$ \\
& & Lateral canal & $31,071.1 \mathrm{c}$ \\
& & Drain 1 & $129,332.5 \mathrm{a}$ \\
\hline
\end{tabular}

Note. Mean values comparison by using Fisher LSD Test at a significance probability $\mathrm{p}<0.01$. The presence of different letters means that there exists a statistical difference. MPN $=$ Most probable number.

All water samples showed presence of E. coli (Figure 4). This bacterium was found in all water samples from streams $(100 \%)$, followed by the samples from irrigation canals $(83 \%)$, deep wells $(30 \%)$ and shallow wells (22\%). Of the total water samples obtained from 32 sampling points, $63 \%$ were from groundwater and $37 \%$ from surface water. Of the groundwater samples analyzed, $27 \%$ were contaminated with $E$. coli and $73 \%$ were 
negative. Among surface water samples, $92 \%$ were positive for E. coli, and $8 \%$ were negative (Figure 5). It has been found that among groundwater samples from deep wells, E. coli and other coliforms increased the total assimilation rate of $\mathrm{NO}_{3}$ and $\mathrm{O}_{2}$ to synthesize amino acids and proteins (Perdomo et al., 2001). The biophysical and environmental conditions, nitrogen content, resistance to $\mathrm{pH}$ conditions and soil factors allow E. coli to survive in groundwater (Cifuentes \& Ruiz, 1994; Juarez, Silva, Uribe, \& Cifuentes, 2003).

Contamination of surface and groundwater by $E$. coli is a risk to public health since this bacterium causes human illnesses such as diarrhea in children and adults, as well as inflammatory diarrhea. The latter is characterized primarily by bacteria attacking intestinal epithelia (Landeros-Sánchez et al., 2012). In Figures 3 and 4, values for $E$. coli exceeded the limits set by the official standard NOM-127-SSA1 1994; water for potable use and consumption should not contain $E$. coli. Several groups of these bacteria can severely affect children 1 to 8 years of age and cause death, especially if Hemolytic Uremic Syndrome (HUS) is involved, which primarily occurs when water contaminated with this bacteria is ingested (Michanie, 2003; Perez, Rodriguez, \& Rulli, 2009). Therefore, it is recommended that water be tested for the presence of Escherichia coli, particularly enteropathogenic E. coli (EPEC), which causes diarrhea in children less than two years of age in developing countries. This pathogen causes histological damage to the mucosa of the small intestine and can cause death in children (Vidal, Canizalez, Gutierrez, \& Navarro, 2007). Thus, health authorities in Mexico (federal, state and local, and public health institutions) must monitor water bodies vigilantly to ensure that official standards are not being surpassed and that the tests are effective and timely.

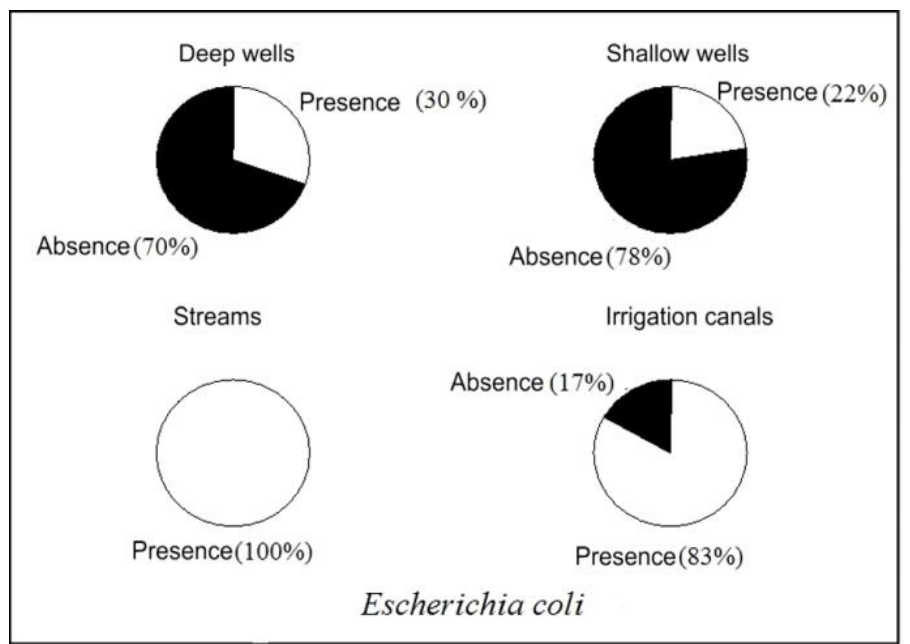

Figure 4. Percentage of water samples from deep and shallow wells, streams and irrigation canals showing presence or absence of Escherichia coli

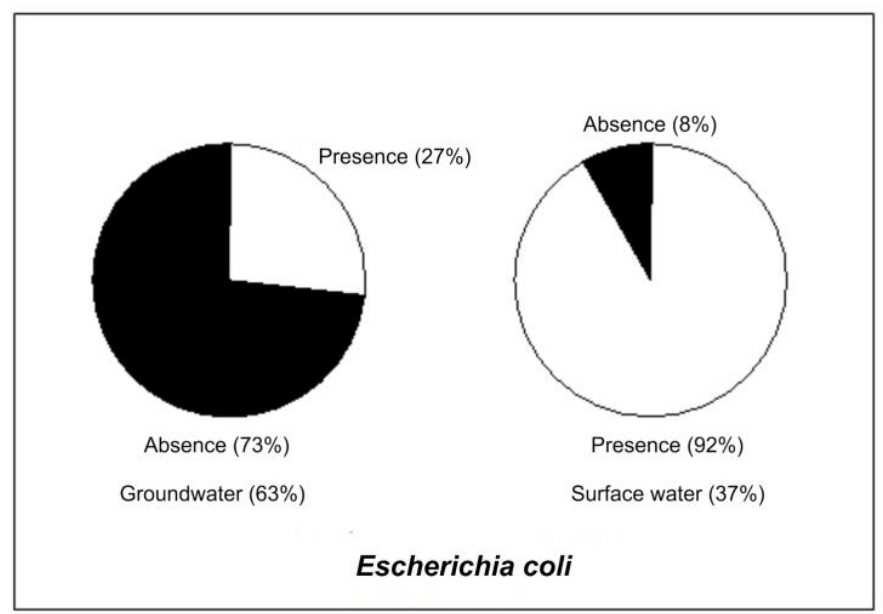

Figure 5. Percentage of samples of ground and surface water from Irrigation Module I-1, La Antigua, showing the presence or absence of Escherichia coli 
Surface waters transport high concentrations of coliform bacteria and E. coli into groundwater, revealing that bacterial contamination of groundwater occurs due to runoff and infiltration processes (Ferguson, De Rodahusman, Altavilla, Deere, \& Ashbolt, 2003; Guber, Sheldon, \& Pachepsky, 2005). The approach used in the present study (Figure 6) facilitated understanding of the phenomenon and identification of point sources of bacterial contamination occurring within sugarcane Irrigation Module I-1, La Antigua. Therefore, point sources of bacterial contamination were identified as septic tanks, latrines, and sewage discharges to streams, irrigation canals and drains.

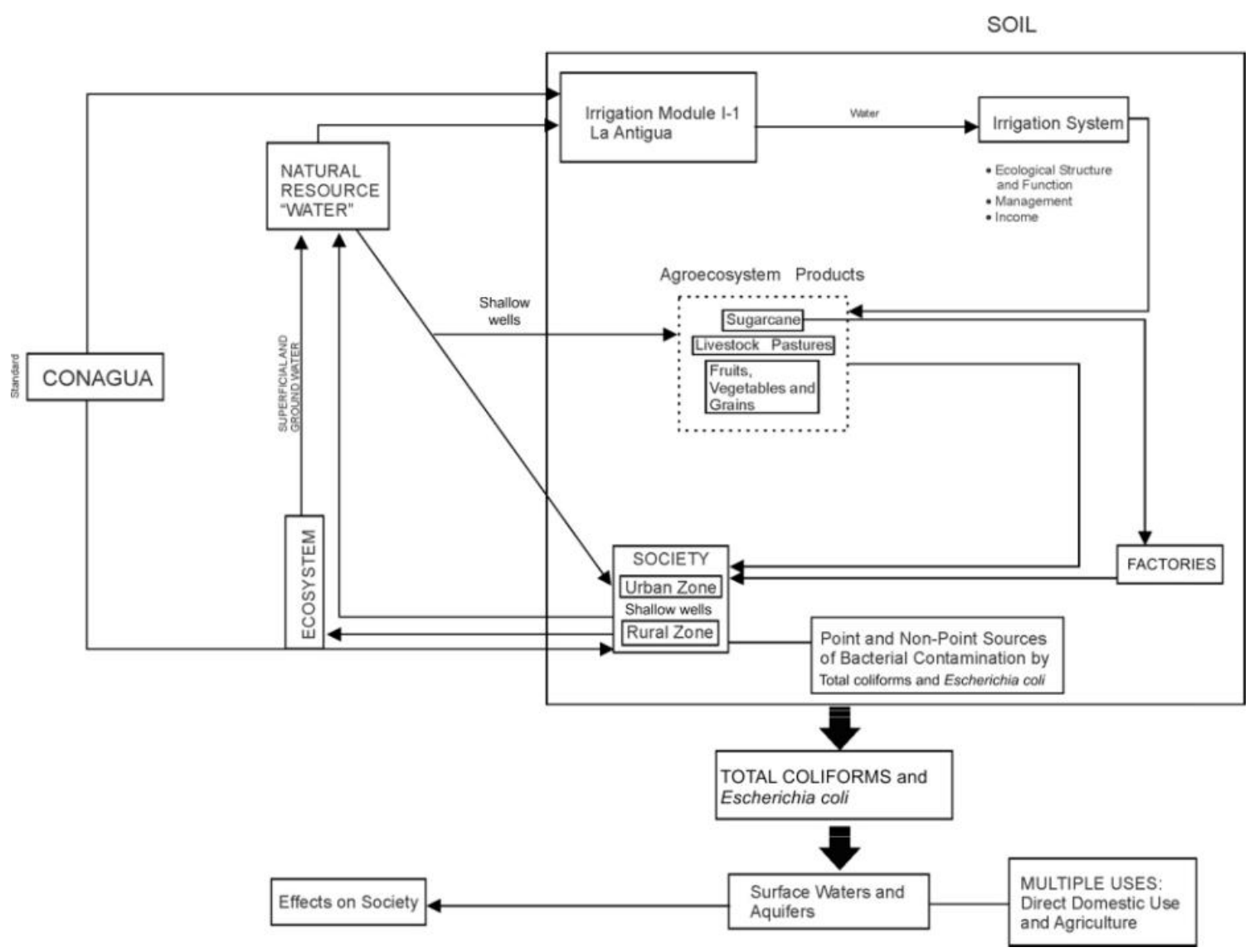

Figure 6. Conceptual model for studying contamination from total coliforms and Escherichia coli in sugarcane Irrigation Module I-1, La Antigua

\section{Conclusions}

The concentration of total coliforms and E. coli in both surface and groundwater from deep and shallow wells, streams and irrigation canals exceeded permissible limits (NOM-127-SSA1-1994, Mexican Official Standard for human use and consumption). The concentration of total coliforms from deep and shallow wells did not exceed the maximum permissible limits for contaminants (NOM-033-ECOL-1997, Wastewater). Contamination from total coliform bacteria and $E$. coli was provided by point sources such as septic tanks, sewage and hospital waste which are discharged into irrigation canals and streams. In addition, some portion of the total coliforms and $E$. coli that enter the water conveyance system used to irrigate sugarcane comes from the La Antigua River, which supplies Irrigation Module I-1, La Antigua. Therefore, contamination and pollution from total coliform bacteria and $E$. coli are risks to the health of the residents of the urban and rural areas contained therein. Thus, it is necessary to establish a culture of environmental stewardship, particularly water quality, to ensure that Mexican Official Standards be applied efficiently in order to prevent further negative impacts to the environment and public health.

\section{Acknowledgements}

To Colegio de Postgraduados Campus Veracruz (LPI-8 Impacto y Mitigación del Cambio Climático) and to the Instituto Tecnológico de Boca del Río (ITBOCA) for financial support. Thanks also to Ing. Juan Manuel 
Hernández Pérez for assistance in the preparation of tables and figures.

\section{References}

Bautista, F., Aguilar, D. Y., \& Batllori, E. (2011). Amenazas, vulnerabilidad y riesgo de contaminación de las aguas subterráneas en la península de Yucatán. Teoría y Praxis, 9, 9-31.

Camargo, J. A., \& Alonso, A. (2007). Contaminación por nitrógeno inorgánico en los ecosistemas acuáticos: problemas medioambientales, criterios de calidad del agua, e implicaciones del cambio climático. Ecosistema, 16, 98-110.

Castañeda, M., Pardio, S., Orrantia, B., \& Lango, F. (2005). Influence of water temperature and salinity on seasonal occurrences of Vibrio cholerae and enteric bacteria in oyster-producing areas of Veracruz, México. Marine Pollution Bulletin, 50, 1641-1648. http://dx.doi.org/10.1016/j.marpolbul.2005.06.036

Chagas, C. I., Morettón, J., Santanatoglia, O. J., Paz, M., Muzio, H., De Siervi, M., \& Castiglioni, M. (2006). Indicadores de contaminación biológica asociados a la erosión hídrica en una cuenca de pampa ondulada Argentina. CI. Suelo, 24, 1-10.

Cifuentes, E., \& Ruiz, P. G. (1994). Escenarios epidemiológicos del uso agrícola del agua residual: el valle del Mezquital, México. Salud Pública de México, 36, 3-9.

De la Heras, I. J., \& Moreno, A. J. L. (2005). La calidad del agua contaminación de las aguas producida por la agricultura. Limitaciones para su uso en la agricultura. In O. M. F. Martín de Santa, F. P. López \& B. A. Calera (Eds.), Agua y Agronomía (pp. 295-318). Grupo Mundi Prensa. Madrid, España.

Del Ángel, P. A. L., Díaz, P. G., Guajardo, P. R., \& Linares, B. B. C. (2011). Landscapes and fragile economy: ecosystems and agroecosystems in the Coatepec - La Antigua basin, Veracruz, Mexico. Tropical and Subtropical Agroecosystems, 14, 629-642.

Ferguson, C., De Roda Husman, A. M., Altavilla, N., Deere, D., \& Ashbolt, N. (2003). Fate and transport of surface water pathogens in watersheds. Critical Reviews in Environmental Science and Technology, 33, 299-361. http://dx.doi.org/10.1080/10643380390814497

Galaviz-Villa, I., Landeros, S., Castañeda-Chávez, M. del R., \& Lango, R. (2012). Theoretical conceptual assembly for the analysis of sugarcane agroecosystems in the central Gulf of Mexico: an eclectic model. Journal of Agricultural Science, 4, 214-220. http://dx.doi.org/10.5539/jas.v4n12p214

Gordillo, M. A. J., Cabrera, C. R. B. E., Hernández, M. M., Galindo, E., Otazo, E., \& Prieto, F. (2010). Evaluación regional del impacto antropogénico sobre el aire, agua y suelo, caso: Huasteca Hidalguense, México. Revista Internacional de Contaminación Ambiental, 26, 229-251.

Guber, A. K., Shelton, D. R., \& Pachepsky, Y. A. (2005). Effect of manure on Escherichia coli attachment to soil. Journal of Environmental Quality, 34, 2086-2090. http://dx.doi.org/10.2134/jeq2005.0039

Herrero, M. A., Maldonado, M. V., Sardi, G., Flores, M., Orlando, A., \& Carbo, L. (2000). Distribución de la calidad del agua subterránea en sistemas de producción agropecuarios bonaerenses. 2. Condiciones de manejo y grado de contaminación. Revista Argentina Producción Animal, 20(3-4), 237-245.

Hogan, M. C. (2014). Water pollution. In C. Cleveland (Ed.), Encyclopedia of Earth. Washington, DC: Mark McGinley.

Juárez, F. L. A., Silva, S. J., Uribe, S. F. J., \& Cifuentes, G. E. (2003). Microbiological indicators of water quality in the Xochimilco Canals, Mexico City. Salud Pública de México, 45, 389-395.

Juárez, M. J., Martínez, R. G., Díaz, S. J., Pérez, G. M. L., \& Brust, C. H. (1990). Evaluación del sistema integral para tratamiento del agua en un hospital general de la Ciudad de México. Salud Pública, 32, 566-574.

Krupa, S. V. (1999). Polución, población y plantas. Editorial Mexicana. Edición Rogelio Dromundo Salazar. Registro Número 306 (p. 184).

Landeros-Sánchez, C., Lango-Reynoso, F., Castañeda-Chávez, M. del R., Galaviz, V. I., Nikolskii, G. I., Palomarez, G. M., ... Mínguez, R. M. M. (2012). Assessment of water pollution in different aquatic systems: aquifers, aquatic farms on the Jamapa River and coastal lagoons of Mexico. Journal of Agricultural Science, 4, 186-196. http://dx.doi.org/10.5539/jas.v4n7p186

Lango, F., Castañeda-Chávez, M., Zamora-Castro, J. E., Hernández-Zárate, G., Ramírez-Barragán, M. A., \& Solís-Morán, E. (2012). La acuariofilia de especies ornamentales marinas: un mercado de retos y 
oportunidades. Latin American Journal of Aquatic Research, 40, 12-21. http://dx.doi.org/10.3856/vol40-issue1-fulltext-2

Martínez, D. J. P., Gallardo, L. F., Bustillo, G. L. C., \& Pérez, V. A. (2011). El agroecosistema, unidad de estudio y transformación de la diversidad agrícola. In Comisión Nacional para el Conocimiento y Uso de la Biodiversidad (CONABIO), La Biodiversidad en Veracruz: Estudio de Estado (Volumen I, pp. 453-462). Gobierno del Estado de Veracruz, Universidad Veracruzana, Instituto de Ecología, A.C. México.

Martínez, R. A., Fonseca, G. K., Ortega, S. J. L., \& García, L. C. (2009). Monitoreo de la calidad microbiológica del agua en la cuenca hidrológica del Río Nazas, México. Revista Química Viva, 8, 35-47.

Méndez, N. R. I., San Pedro, C. L., Castillo, B. E. R., \& Vázquez, B. E. (2010). Modelación del tiempo de conservación de muestras biológicas de agua. Revista Internacional de Contaminación Ambiental, 26, 327-335.

Michanie, S. (2003). Escherichia coli O157:H7: la bacteria que disparó el HACCP en la industria de la carne. Énfasis Alimentos, 9, 1-7.

Moreno, C. P., Rojas, G. J. L., Zárate, L. D., Ortiz, P. A., Lara, D. A. L., \& Saavedra, V. T. (2002). Diagnóstico de los manglares de Veracruz: distribución, vínculo con los recursos pesqueros y su problemático. Madera y Bosques, 8, 61-88.

NMX-AA-003. (1980). Norma Oficial Mexicana. Aguas residuales. Muestreo. Retrieved from http://www.conagua.gob.mx/CONAGUA07/Noticias/NMX-AA-003-1980.pdf

NMX-AA-042. (1987). Norma Oficial Mexicana. Calidad del agua determinación del número más probable (NMP) de coliformes totales, coliformes fecales (termotolerantes) y Escherichia coli. Presuntiva, 1-21. Retrieved from http://www.conagua.gob.mx/CONAGUA07/Noticias/NMX-AA-042-1987.pdf

NOM-014-SSA1. (1993). Norma Oficial Mexicana. Procedimientos sanitarios para el muestreo de agua para uso y consumo humano en sistemas de abastecimiento de agua publicos y privados. Retrieved from http://www.salud.gob.mx/unidades/cdi/nom/014ssa13.html

NOM-033-ECOL. (1997). Norma Oficial Mexicana. Límites máximos permisibles de contaminantes para las aguas residuales tratadas que se reúsan en servicios al público. Retrieved from http://www.elaw.org/system/files/NOM-003-ECOL-1997.pdf

NOM-127-SSA1. (1994). Norma Oficial Mexicana. Salud ambiental, agua para uso y consumo humano-límites permisibles de calidad y tratamientos a que debe someterse el agua para su potabilización. Retrieved from http:/www.salud.gob.mx/unidades/cdi/nom/127ssa14.html

NOM-230-SSA1. (2002). Norma Oficial Mexicana. Salud ambiental. Agua para uso y consumo humano, requisitos sanitarios que se deben cumplir en los sistemas de abastecimiento públicos y privados durante el manejo del agua. Procedimientos sanitarios para el muestreo. Retrieved from http://www.salud.gob.mx/unidades/cdi/nom/230ssa102. html

Orozco, B. V., \& Gutiérrez, G. E. A. (1983). Contaminación fecal contera en la zona del Puerto de Ensenada, Baja California. Ciencias Marinas, 9, 27-34.

Pacheco, A. J., Cabrera, S. A., \& Pérez, C. R. (2004). Diagnóstico de la calidad de agua subterránea en los sistemas municipales de abastecimiento en el Estado de Yucatán, México. Ingeniería, 8, 165-179.

Perdomo, C. H., Casanova, O. N., \& Ciganda, V. S. (2001). Contaminación de aguas subterráneas con nitratos y coliformes en el litoral sudoeste del Uruguay. Agrociencia, 5(1), 10-22.

Pérez, V. A., \& Landeros, S. C. (2009). Agricultura y deterioro ambiental. Elementos: Ciencia, Arte y Cultura, $16(73), 19-25$.

Pérez, C., Rodríguez, D., \& Rulli, F. (2009). Innovación docente. Infecciones infantiles provocadas por Escherichia coli: síndrome urémico hemolítico y otras. Revista Iberoamericana de Educación, 50, 1-9.

Ramírez, S. J., Contreras, F. G., \& Gómez, E. M. C. (2005). La fase estacionaria en la bacteria Escherichia coli. Revista Latinoamericana de Microbiología, 43, 92-101.

Rebolledo, M. A., Del Ángel, P. A. L., Megchún, G. J. V., Adame, G. J., Nataren, V. J., \& Capetillo, B. A. (2011). Coberteras vivas para el manejo de malezas en mango (Mangifera indica L.) cv. Manila. Tropical and Subtropical Agroecosistemas, 13, 327-338. 
Sarabia, M. I. F., Cisneros, A. R., Aceves De, A. J., Durán, G. H. M., \& Castro, L. J. (2011). Calidad del agua de riego en suelos agrícolas y cultivos del Valle de San Luis Potosí, México. Revista Internacional de Contaminación Ambiental, 27, 103-113.

Sasson, A. (1993). La alimentación del hombre del mañana (p. 807). UNESCO.

Vidal, J. E., Canizález, R. A., Gutiérrez, J. J., \& Navarro, G. F. (2007). Patogénisis molecular, epidemiología y diagnóstico de Escherichia coli enteropatógena. Salud Pública de México, 49, 376-386. http://dx.doi.org/10.1590/S0036-36342007000500008

Wong, I., \& Barrera, G. (1996). Niveles de contaminación microbiológica en el Golfo de México. In A. V. Botello, G. J. L. Rojas, J. Benítez \& L. D. Zárate (Eds.), Golfo de México, Contaminación e Impacto Ambiental: Diagnóstico y Tendencias (pp. 383-397). EPOMEX Serie Científica 5. Universidad Autónoma de Campeche México.

\section{Copyrights}

Copyright for this article is retained by the author(s), with first publication rights granted to the journal.

This is an open-access article distributed under the terms and conditions of the Creative Commons Attribution license (http://creativecommons.org/licenses/by/3.0/). 